\title{
Controversies in $\mathrm{CO}_{2}$ Insufflation and COVID-19
}

\author{
Mark Soliman ${ }^{1}$
}

Received: 10 May 2020 / Accepted: 10 May 2020 / Published online: 20 May 2020

(c) Springer Nature Switzerland AG 2020

Concern over $\mathrm{CO}_{2}$ insufflation in the era of COVID-19 in endoscopy, laparoscopy, and robotics has been at the forefront of many debates and societal publications. Data at best is murky and confusing, but most importantly is based on speculation and extrapolation from a mixture of older and newer studies [1,2].

With specific reference to this ongoing pandemic, Coronaviruses are a family of ribonucleic acid (RNA) viruses that are implicated in a host of respiratory illnesses spanning from the common cold, Severe acute respiratory syndrome coronavirus (SARS-CoV), to Middle East respiratory syndrome coronavirus (MERS-CoV) [3]. Of most pressing concern is the novel SARS-CoV-2, which was dubbed coronavirus disease 2019 (COVID-19) by the World Health Organization in late 2019 [4].

This RNA virus has a size range of $0.06-0.14$ microns [5] and has been isolated within the epithelium of both the respiratory and gastrointestinal (GI) tract. Authors have demonstrated that viral RNA is shed in the stool of infected pediatric patients well after viral respiratory shedding has resolved, thus raising concern of any GI instrumentation as high risk [6]. Unfortunately, at the time of this publication, it is unknown if COVID-19 can be isolated from the peritoneal surface or ascitic fluid, but studies are currently underway.

Of most imminent concern is the viral aerosolization. Historically, studies have shown that many viruses may be aerosolized by cauterizing tissue of an infected host, including human papilloma virus (HPV), human immunodeficiency virus (HIV), and hepatitis $\mathrm{N}$ virus/HBV) [7]. To date, COVID-19 has not been specifically studied for aerosolization propensity but the concept and concern are sound nonetheless.

Within this framework lies the dilemma and controversy: are we to assume this unproven fear of COVID-19 aerosolization during surgery and instrumentation? If not, do we

Mark Soliman

mark@marksoliman.com

1 Colon and Rectal Clinic of Orlando, Orlando, FL, USA approach patients as "business as usual" and continue care without regard for this until studies catch up to either prove or disprove this theory? Or, if we do choose to succumb to this theory, how then do we react to mitigate this risk until further virologic studies aid in clarifying this contentious point?

For the latter, the forthcoming is an overview of what data we do know and the mitigating factors many are employing.

Likely the best way to avoid aerosolization altogether is to avoid cautery or fulguration entirely. For this reason, nearly all surgical societies have advocated simply not operating unless absolutely mandatory [8-10]. Other recommendations include eliminating use of energy devices altogether-or use at their absolute lowest settings, maintaining pneumoperitoneum at its lowest possible setting if performing laparoscopy, and evacuating all insufflated air prior to specimen extraction [9].

In regard to minimizing transmission of possibly aerosolized COVID-19 that is created during an operation, the topic of smoke evacuation and filtration is of paramount importance.

Whether an operation is performed in an open manner, laparoscopically, or robotically-assisted, smoke plumes are inevitably created while employing energy devices. In minimally invasive operations that require $\mathrm{CO}_{2}$ insufflation, depending on the insufflator used, filtration may or may not occur during the entirety of the case. Knowing the viral particle size of COVID-19 ranges from 0.06 to 0.14 microns, the primary concern arises if improperly sized filters are utilized to evacuate smoke plumes. This means that during the progress of a laparoscopic or robotic operation, $\mathrm{CO}_{2}$ enters in via an inflow cannula and either the $\mathrm{CO}_{2}$ remains trapped intraabdominally (along with aerosolized virus), or it is recirculated through the insufflator, filtered, then exhausted through the back of the insufflator as room air. If a $\mathrm{CO}_{2}$ insufflation filter (or a handheld suction device in an open operation) is too large to capture the smaller RNA viral particles, aerosolized viral particles are essentially being concentrated within the exhaust and then expelled out of the rear of the insufflator. 
Proper $\mathrm{CO}_{2}$ filtration in laparoscopy is critical. Only two insufflators are commercially available that filter viral particles in the range of COVID-19. Those are CON-MED Airseal (which filters down to 0.01 micron) [11] (Figs. 1 and 2) and Stryker's PnemoClear (Fig. 3) (which filters down to 0.05 microns) [12]. As of this writing, there are no other insufflators available that will adequately filter down to the size of the COVID-19 virions to mitigate this potential threat.

It is also important to note that there are two different devices that are available from CON-MED which both utilize a 0.01 micron filter: the ASM-EVAC and SEM-EVAC systems.

The CON-MED Airseal, model ASM-EVAC utilizes a trifurcated tubing system and a proprietary valveless trocar (Fig. 1). This valveless trocar is known to allow pneumoperitoneum to escape during operations with an increase in intraabdominal pressure or during instrument exchange (see "Insufflation Recommendations. CONMED Corporation"). This open-circuit should be avoided to circumvent a jet-like stream of aerosolized virions within the pneumoperitoneum. CON-MED has published mitigation strategies by using constant negative pressure smoke evacuators on other valved ports, but this does not stop valveless trocar leak, it only tries to minimize it. For this reason, a closed circuit such as the SEM-EVAC should be used, which does not employ valveless trocars, but, in fact, uses standard, valved ports.

The second commercially available insufflator is the Stryker PneumoClear (Fig. 3). The PneumoClear Tube Set

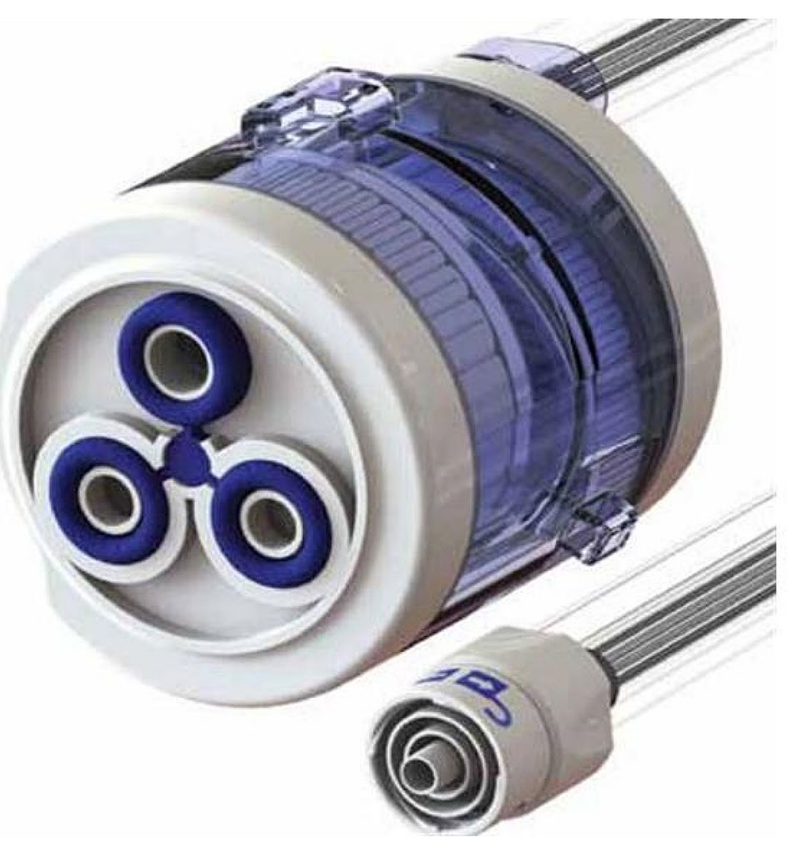

Fig. 1 CON-MED Airseal, Model ASM-EVAC, reproduced with permission

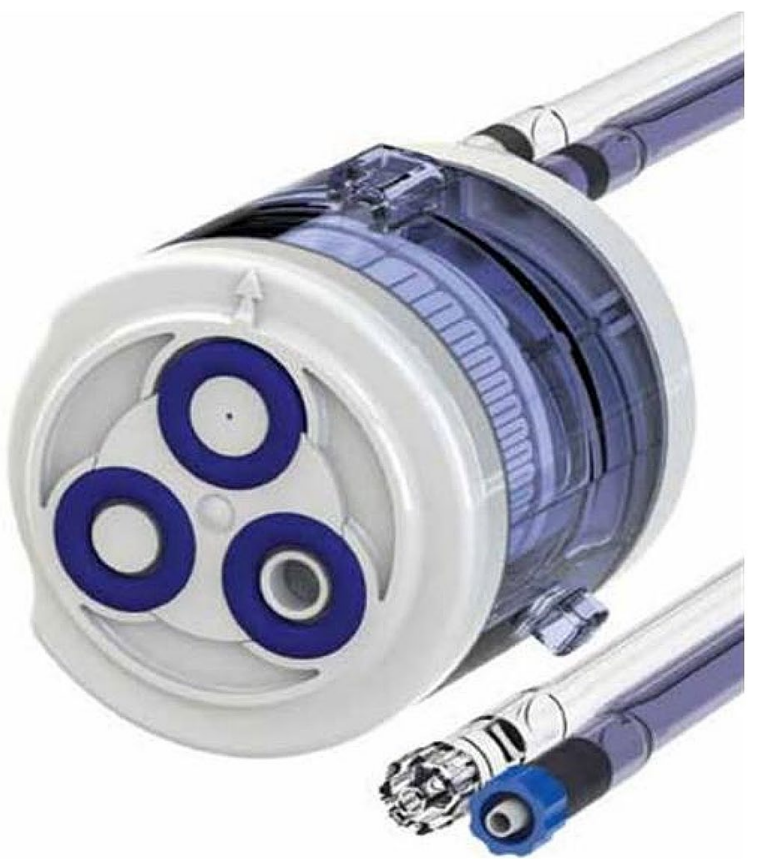

Fig. 2 CON-MED Airseal, Model SEM-EVAC, reproduced with permission

consists of a series of filters: one absorbent layer, one ULPA filter, one PVDF filter, and two charcoal layers. These tube sets filter particles as small as 0.051 microns with up to 99.999993\% efficiency for outflow and are secured using non-proprietary and valved trocars [13].

Furthermore, it is reasonable to be concerned of the imminent risk of insufflated intraabdominal $\mathrm{CO}_{2}$ to leak into the room air of the operating room (for instance from port site air leaks, valves inadvertently being stuck in the open position, ports sliding out, during instrument exchanges, during specimen extraction). For this reason, societies have published strategies to prevent/minimize this (Table 1 , SAGES [14]).

To deal with the problem infiltration of potential aerosolized virus that escapes the operative field, another

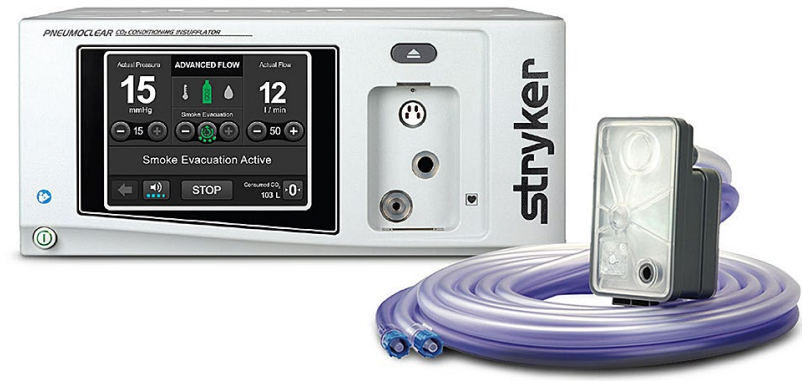

Fig. 3 Stryker PneumoClear 
Table 1 SAGES. Practical Measures for Use of Filtration During Laparoscopy

Practical measures for use of filtration during laparoscopy:

1. All pneumoperitoneum should be safely evacuated from the port attached to the filtration device before closure, trocar removal, specimen extraction or conversion to open

2. Once placed, ports should not be vented if possible. If the movement of the insufflating port is required, the port should be closed prior to disconnecting the tubing and the new port should be closed until the insufflator tubing is connected. The insufflator should be "on" before the new port valve is opened to prevent gas from back-flowing into the insufflator

3. During desufflation, all escaping $\mathrm{CO}_{2}$ gas and smoke should be captured with an ultra-filtration system and desufflation mode should be used on your insufflator if available

4. If the insufflator being used does not have as desufflation feature, be sure to close the valve of the working port that is being used for insufflation before the flow of $\mathrm{CO}_{2}$ on the turned off (even if there is an in-line filter in the tubing). Without taking this precaution contaminated intra-abdominal $\mathrm{CO}_{2}$ can be pushed into the insufflator when the intraabdominal pressure is higher than the pressure within the insulator

5. The patient should be flat and the least dependent port should be utilized for desufflation

6. Specimens should be removed once all the $\mathrm{CO}_{2}$ gas and smoke is evacuated

7. Surgical drains should be utilized only if absolutely necessary

8. Suture closure devices that allow for leakage of insufflation should be avoided. The fascia should be closed after desufflation

9. Hand-assisted surgery can lead to significant leakage of insufflated $\mathrm{CO}_{2}$ and smoke from ports and should be avoided. If used to remove

larger specimens and protect the wound, it can be placed after desufflation. The specimen can then be removed and the closure performed

important consideration is donning proper masks. Much has been written and incredible amounts of attention within the public media has been given to personal protective equipment and N95 masks. It is sufficient to say that this attention is warranted as the supply of this equipment is of paramount importance for the safety of at-risk health care providers and improper use may deplete an already critical supply. That said, a primer on the utility and efficacy of surgical masks and personal protective equipment (PPE) is also warranted.

"N95 respirators made by different companies were found to have different filtration efficiencies for the most penetrating particle size (0.1-0.3 micron), but all were at least $95 \%$ efficient at that size for $\mathrm{NaCl}$ particles" [15]. To obtain the stated filtration rate, N95 masks require a fit test and a tight seal around the mouth and nose to afford maximal (yet still imperfect) benefit. Surgical masks, on the other hand, are loose fitting, simple disposable barriers and offer little in the way of filtration [16].

In conclusion, although there is much speculation and a paucity of research in the area of aerosolization of COVID19 , it is prudent to err on the side of safety in this controversy and use proper precautionary measures during open, laparoscopic, and robotic procedures.

\section{Compliance with ethical standards}

Conflict of interest The author has no relevant financial disclosures or conflicts of interest.

\section{References}

1. Zheng MH, Boni L, Fingerhut A (2020) Minimally invasive surgery and the novel coronavirus outbreak: lessons learned in China and Italy [published online ahead of print, 2020 Mar 26]. Ann Surg. https://doi.org/10.1097/sla.0000000000003924

2. Liu Y, Song Y, Hu X, Yan L, Zhu X (2019) Awareness of surgical smoke hazards and enhancement of surgical smoke prevention among the gynecologists. J Cancer. 10(12):2788-2799. https:// doi.org/10.7150/jca.31464 (Published 2019 Jun 2)

3. Cui J, Li F, Shi ZL (2019) Origin and evolution of pathogenic coronaviruses. Nat Rev Microbiol 17(3):181-192. https://doi. org/10.1038/s41579-018-0118-9

4. Naming the Coronavirus Disease (COVID-19) and the Virus That Causes It. World Health Organization, World Health Organization, www.who.int/emergencies/diseases/novel-coronavirus-2019/techn ical-guidance/naming-the-coronavirus-disease-(covid-2019)-andthe-virus-that-causes-it. Accessed 12 Apr 2020

5. Zhu N, Zhang D, Wang W et al (2020) A novel coronavirus from patients with pneumonia in China, 2019. N Engl J Med 382(8):727-733. https://doi.org/10.1056/NEJMoa2001017

6. Xing $\mathrm{YH}, \mathrm{Ni} \mathrm{W}, \mathrm{Wu} \mathrm{Q}$ et al (2020) Prolonged viral shedding in feces of pediatric patients with coronavirus disease 2019 [published online ahead of print, 2020 Mar 28]. J Microbiol Immunol Infect. https://doi.org/10.1016/j.jmii.2020.03.021

7. Alp E, Bijl D, Bleichrodt RP, Hansson B, Voss A (2006) Surgical smoke and infection control. J Hosp Infect 62(1):1-5. https://doi. org/10.1016/j.jhin.2005.01.014

8. COVID-19 and Surgery. American College of Surgeons, www. facs.org/covid-19. Accessed 12 Apr 2020

9. SAGES COVID-19/Coronavirus Announcement Archives. Society of American Gastrointestinal and Endoscopic Surgeons, https ://www.sages.org/category/covid-19. Accessed 12 Apr 2020

10. COVID-19 Statements. European Association for Endoscopic Surgery, https://eaes.eu/category/covid-19-statements/. Accessed 12 Apr 2020

11. Air-Seal IFS. CON-MED, https://www.conmed.com/en/medic al-specialties/laparoscopic-robotic-and-open-surgery/generaland-bariatric-surgery/access/airseal-system/airseal-products/airse al-ifs-intelligent-flow-system. Accessed 12 Apr 2020 
12. PneumoClear Insufflation. Stryker, https://www.stryker.com/us/ en/endoscopy/products/pneumoclear.html. Accessed 12 Apr 2020

13. Endoscopy. Society of American Gastrointestinal and Endoscopic Surgeons, https://www.sages.org/wp-content/uploads/2020/03/ PneumoClear-Memo.pdf. Accessed 12 Apr 2020

14. Resources For Smoke \& Gas Evacuation During Open, Laparoscopic, And Endoscopic Procedures. Society of American Gastrointestinal and Endoscopic Surgeons, https://www.sages.org/resou rces-smoke-gas-evacuation-during-open-laparoscopic-endoscopic -procedures/. Accessed 12 Apr 2020

15. Qian Y, Willeke K, Grinshpun SA, Donnelly J, Coffey CC (1998) Performance of N95 respirators: filtration efficiency for airborne microbial and inert particles. Am Ind Hyg Assoc J 59(2):128-132. https://doi.org/10.1080/15428119891010389

16. N95 Respirators and Surgical Masks (Face Masks).(2020) Retrieved from https://www.fda.gov/medical-devices/personalprotective-equipment-infection-control/n95-respirators-and-surgi cal-masks-face-masks. Accessed 12 Apr 2020

Publisher's Note Springer Nature remains neutral with regard to jurisdictional claims in published maps and institutional affiliations. 